\title{
Analyses of mycotoxins in broiler's local and imported feeds
}

\author{
N.M.S. Bibani ${ }^{1}$, Z.K. Khidhir ${ }^{2}$, A.S. Shaker ${ }^{3,}$, Sh.M.S. Kirkuki ${ }^{2}$ \\ and S.M. Abdulateef ${ }^{4}$ \\ ${ }^{1}$ College of Veterinary Medicine, Sulaimani University, ${ }^{2}$ Animal Sciences Department, College of Agricultural Sciences, \\ Sulaimani University, ${ }^{3}$ Animal Production Department, Agricultural Research Center, Sulaimani, \\ ${ }^{4}$ Animal Production Department, College of Agriculture, Anbar University, Anbar, Iraq, *E.mail: kosrat_ahmed@yahoo.com
}

(Received August 8, 2018; Accepted October 1, 2018)

\begin{abstract}
In the present study 40 samples of broiler feeds that obtained from commercial feed manufacturing company (concerning 21 from Iraqi manufactures and 19 from the Iranian manufactures) were analyzed for the incidence of Aflatoxins, Ochratoxin, T-2, Fumonisins, and Zearalenone mycotoxins. The result has shown that AF was detected in 16 samples $76.19 \%$ of the Iraqi manufactures and 16 samples $84.21 \%$ from the Iranian manufactures, in concentrations ranging from $1.00-23.00 \mu \mathrm{g} / \mathrm{kg}$, and $1.00-2.00 \mu \mathrm{g} / \mathrm{kg}$ respectively. Prevalence of AF contamination revealed a significant association $(\mathrm{P}<0.05)$ between the Iraqi and Iranian manufactures, the highest prevalence was observed in Iranian samples $84.21 \%$, whereas it least in Iraqi samples $76.19 \%$. OCHRA toxin was detected in 21 samples $100 \%$ of the Iraqi manufactures and 19 samples $100 \%$ from the Iranian manufactures, in concentration ranging from $3.00-4.00 \mu \mathrm{g} / \mathrm{kg}$, and $(2.00-4.00) \mu \mathrm{g} / \mathrm{kg}$ respectively. prevalence of OCHRA contamination revealed a non-significant $(\mathrm{P}>0.05)$ between the Iraqi and Iranian manufactures. T2 toxin was detected in 21 samples $(100 \%)$ of the Iraqi manufactures and 19 samples (100\%) from the Iranian manufactures, in concentration ranging from $(2.00-16.00) \mu \mathrm{g} / \mathrm{kg}$, and $(2.00-23.00) \mu \mathrm{g} / \mathrm{kg}$ respectively. Prevalence of $\mathrm{T} 2$ contamination revealed a significant association $(\mathrm{P}<0.05)$ between the Iraqi and Iranian manufactures FUM3 toxin was detected in 21 samples $(100 \%)$ of the Iraqi manufactures and 19 samples $(100 \%)$ from the Iranian manufactures, in concentration ranging from $(0.05-5.00) \mu \mathrm{g} / \mathrm{kg}$, and $(0.10-2.50) \mu \mathrm{g} / \mathrm{kg}$ respectively. Prevalence of FUM3 contamination revealed a significant association $(\mathrm{P}<0.05)$ between the Iraqi and Iranian manufactures, ZEAR3 toxin was detected in 15 samples $(71.42 \%)$ of the Iraqi manufactures and 19 samples $(100 \%)$ from the Iranian manufactures, in concentration ranging from $(2.00-76.00) \mu \mathrm{g} / \mathrm{kg}$, and $(1.00-41.00) \mu \mathrm{g} / \mathrm{kg}$ respectively. Prevalence of ZEAR3 contamination revealed a significant association $(\mathrm{P}<0.05)$ between the Iraqi and Iranian manufactures, the highest prevalence was observed in Iranian samples (100\%), whereas it least in Iraqi samples (71.42\%).
\end{abstract}

Keywords: Mycotoxins, broiler, feed.

Available online at http://www.vetmedmosul.com

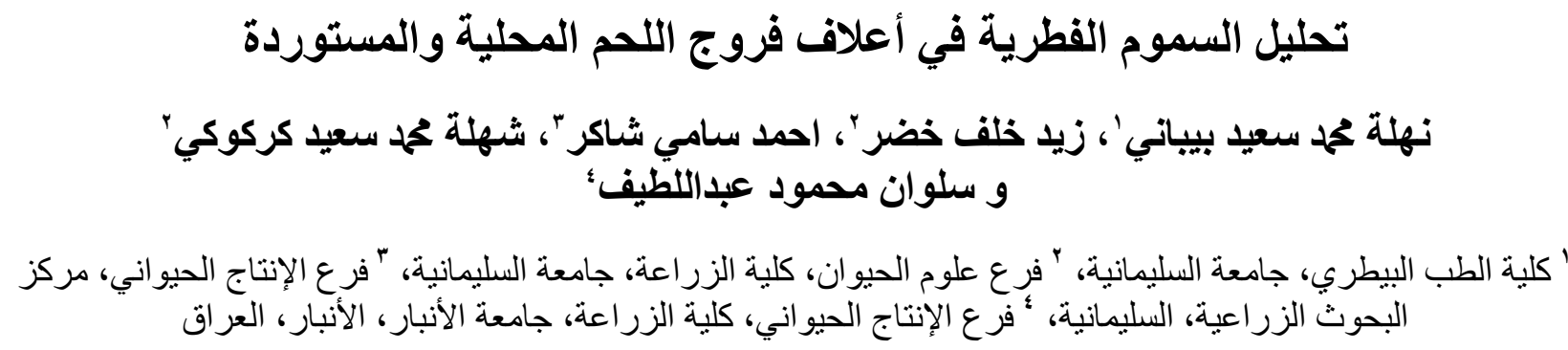

الخلاصة

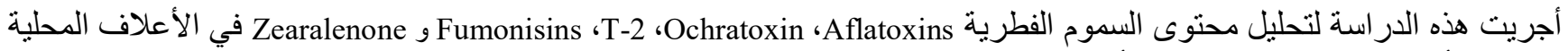

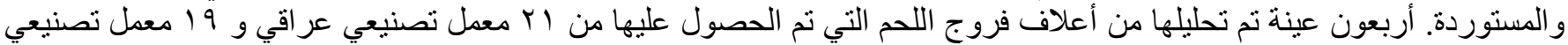

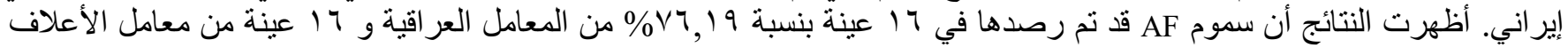

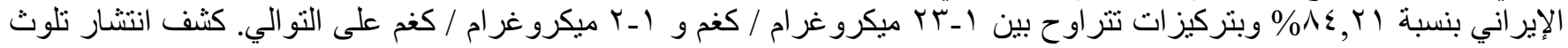




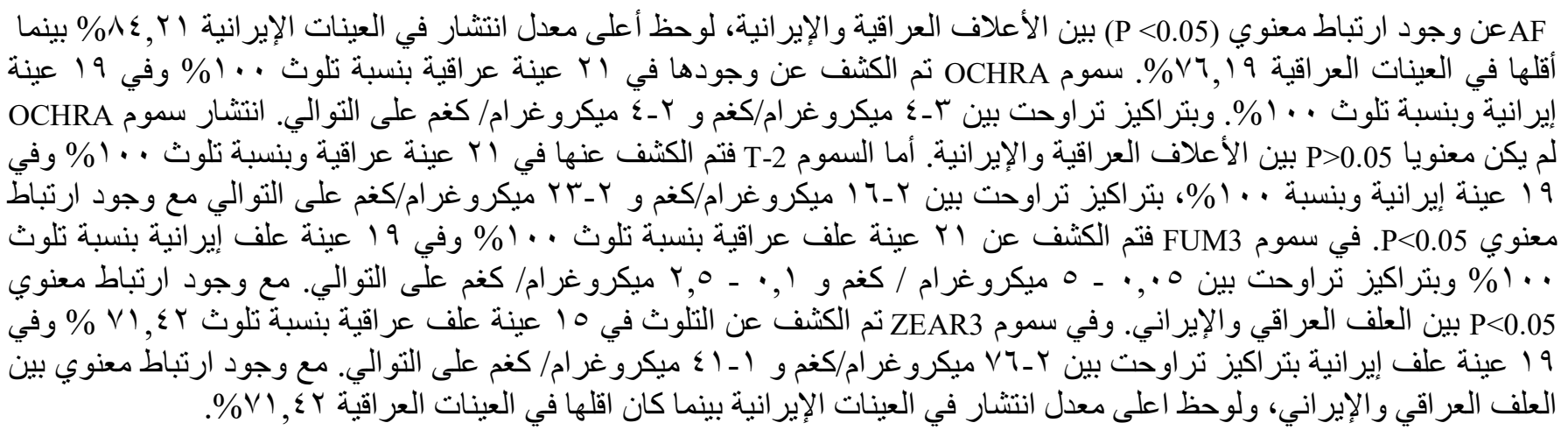

\section{Introduction}

Mycotoxins are highly poisonous secondary metabolites produced by wide range of fungi principally molds. It's presence in poultry feeds result from the raw material used in their production (1-3). In general, mycotoxins can be produced in various food crops in the field, during processing, transportation and storage when conditions such as temperature and relative humidity are favorable (4) specially in tropic and subtropics region, that the environment comfortable for growth of molds and production of toxins. More than 480 compounds are documented as mycotoxins. Aflatoxins, Zearalenone, Ochratoxin, Fumonisins, and T-2 (5) toxin are some of the mycotoxins and each one will be more or less toxic depending on dose and duration of exposure, which represent an excellent substrate growth and reproduction of numerous fungi. Symptoms of mycotoxins toxicity in birds range from death (6) to chronic diseases, reproductive confusion, immune extinction $(7,8)$ and decreased egg production and meat (9). The effect of toxins on the biochemical-hematological (10), immunological (11), and pathological (12) also been well studied.

The objective of the current study is to compare the level of the 5 major mycotoxins in feed samples of broiler from different factories in Kurdistan Governorate region (KGR)-Iraq and Iran.

\section{Materials and methods}

\section{Collecting samples}

The study was conducted during (2013 and 2014) in and around Sulaimani province in KGR-Iraq to determine the AF, OCHRA, T2, FUM3, and ZEAR3 in broiler feed. A total of 40 samples of poultry feed were collected from local poultry farms. The samples were homogenized and quartered to obtain a $1 \mathrm{~kg}$ of laboratory sample. All collected samples were stored at $-20 \mathrm{C}$ prior to analysis and thoroughly ground for analysis.

\section{Analysis procedure}

The concentration of total Aflatoxins, Zearalenone, Ochratoxin, Fumonisins, and T-2 in the feed samples was determined by using the ROSA system (Charm Biosciences Ins., Lawrence, MA, USA). Fifty gram of grinded feed sample was added to $100 \mathrm{ml}$ of $70 \%$ methanol. Then $100 \mu \mathrm{l}$ of extract was added to $1 \mathrm{~mL}$ dilution buffer, then $300 \mu \mathrm{l}$ of the was diluted extract is added to a lateral flow test strip. The test strip was incubated for 10 minutes at $45^{\circ} \mathrm{C}$. The test strip was removed and read in the ROSA-M reader.

\section{Data Analysis}

Data were analysis using T-test procedures, by SPSS v.18 program to assess the differences between the Iraqi factories and the Iranian Factories.

\section{Results and discussion}

In the present study 40 samples of broiler feeds that obtained from commercial feed manufacturing company (concerning 21 from Iraqi manufacture and 19 from the Iranian manufactures) were analyzed for the incidence of AF, OCHRA, T-2, FUM3, and ZEAR3. The total samples number, positive samples, negative samples, and the percentage of the positive samples were presented in the table 1. The Mean \pm S.E., Max, Min, and $\mathrm{P}$ value concentration of the contaminated samples by AF, OCHRA, T2, FUM3, and ZEAR3, were represented in table 2.

The result has shown that AF was detected in 16 samples $(76.19 \%)$ of the Iraqi manufactures and 16 samples (84.21\%) from the Iranian manufactures (Table 1), in concentrations ranging from $1.00-23.00 \mu \mathrm{g} / \mathrm{kg}$, and $1.00-$ $2.00 \mu \mathrm{g} / \mathrm{kg}$ respectively. Prevalence of AF contamination revealed a significant association $(\mathrm{P}<0.05)$ between the Iraqi and Iranian manufacture, the highest prevalence was observed in Iranian samples $84.21 \%$, whereas it least in Iraqi samples $76.19 \%$. The presence of Aflatoxins in animal feeds causes delayed growth of farm animals and, accordingly, a huge economic loss (13). Some of the 
samples exceed the acceptable level according to (14) which mentioned that the accepted level of $20 \mathrm{ppb}$ aflatoxins in poultry feed. It has been well documented that aflatoxin is the most commonly known mycotoxin in poultry feed associated with storage development, but a number of other mycotoxins can also result in adverse effects. In Turkey, $71 \%$ of the 52-layer feed samples generally contained $<5 \mathrm{ppb}$ aflatoxins, and only two samples exceeded 20n ppb tolerance levels (15). Aflatoxin contamination in poultry feed reported from India and Bangladesh was considerably more than found in our study.
The levels in poultry feed in Bangladesh ranged from 7 to160 ppb, whereas $60 \%$ of the samples of mixed feed found in India contained $>10 \mathrm{ppb}$ Aflatoxins $(16,17)$. Other study in Kuwait revealed average aflatoxin concentration in maize at $0.27 \mathrm{ppb}$ (range from 0 to $1.69 \mathrm{ppb}$ ), soybean meal at $0.20 \mathrm{ppb}$ (range from 0 to $1.27 \mathrm{ppb}$ ), wheat bran at 0.15 $\mathrm{ppb}$ (range from 0 to $1.07 \mathrm{ppb}$ ), prepared poultry feed for broiler starter at $0.48 \mathrm{ppb}$ (range from 0 to $3.26 \mathrm{ppb}$ ), broiler finisher at $0.39 \mathrm{ppb}$ (range from 0 to $1.05 \mathrm{ppb}$ ), and layer mash at $0.21 \mathrm{ppb}$ (range from 0 to $1.30 \mathrm{ppb}$ ) (18).

Table 1: Occurrence of mycotoxins in poultry feed from local and imported

\begin{tabular}{lcccccccc}
\hline \multirow{2}{*}{ Toxin } & \multicolumn{9}{c}{ Iraq } & \multicolumn{2}{c}{ Iran } \\
\cline { 2 - 9 } & $\begin{array}{c}\text { Number of } \\
\text { samples }\end{array}$ & $\begin{array}{c}\text { Positive } \\
\text { samples }\end{array}$ & $\begin{array}{c}\text { Negative } \\
\text { samples }\end{array}$ & $\begin{array}{c}\text { \% of positive } \\
\text { samples }\end{array}$ & $\begin{array}{c}\text { Number of } \\
\text { samples }\end{array}$ & $\begin{array}{c}\text { Positive } \\
\text { samples }\end{array}$ & $\begin{array}{c}\text { Negative } \\
\text { samples }\end{array}$ & $\begin{array}{c}\text { \% of positive } \\
\text { samples }\end{array}$ \\
\hline AF & 21 & 16 & 5 & 76.19 & 19 & 16 & 3 & 84.21 \\
OCHRA & 21 & 21 & 0 & 100 & 19 & 19 & 0 & 100 \\
T2 & 21 & 21 & 0 & 100 & 19 & 19 & 0 & 100 \\
FUM3 & 21 & 21 & 0 & 100 & 19 & 19 & 0 & 100 \\
ZEAR3 & 21 & 15 & 6 & 71.42 & 19 & 19 & 0 & 100 \\
\hline
\end{tabular}

Table 2: Descriptive mycotoxin analyses of broiler feed from local and imported

\begin{tabular}{|c|c|c|c|c|c|c|c|c|c|}
\hline \multirow[b]{2}{*}{ Toxin } & \multicolumn{4}{|c|}{ Iraq } & \multicolumn{4}{|c|}{ Iran } & \multirow[b]{2}{*}{ P-value } \\
\hline & $\begin{array}{c}\text { Number of } \\
\text { samples }\end{array}$ & $\begin{array}{c}\text { Mean } \pm \text { S.E. } \\
\mu \mathrm{g} / \mathrm{kg}\end{array}$ & $\begin{array}{l}\text { Max. } \\
\mu \mathrm{g} / \mathrm{kg}\end{array}$ & $\begin{array}{l}\text { Min. } \\
\mu \mathrm{g} / \mathrm{kg}\end{array}$ & $\begin{array}{c}\text { Number of } \\
\text { samples }\end{array}$ & $\begin{array}{c}\text { Mean } \pm \text { S.E. } \\
\mu \mathrm{g} / \mathrm{kg}\end{array}$ & $\begin{array}{l}\text { Max. } \\
\mu \mathrm{g} / \mathrm{kg}\end{array}$ & $\begin{array}{l}\text { Min. } \\
\mu \mathrm{g} / \mathrm{kg}\end{array}$ & \\
\hline $\mathrm{AF}$ & 21 & $3.19 \pm 1.23$ & 23.00 & 0.00 & 19 & $0.94 \pm 0.12$ & 2.00 & 0.00 & 0.003 \\
\hline OCHRA & 21 & $3.52 \pm 0.11$ & 4.00 & 3.00 & 19 & $3.63 \pm 0.13$ & 4.00 & 2.00 & 0.936 \\
\hline $\mathrm{T} 2$ & 21 & $6.00 \pm 0.73$ & 16.00 & 2.00 & 19 & $7.52 \pm 1.41$ & 23.00 & 2.00 & 0.020 \\
\hline FUM3 & 21 & $1.40 \pm 0.28$ & 5.00 & 0.05 & 19 & $0.94 \pm 0.15$ & 2.50 & 0.10 & 0.027 \\
\hline ZEAR3 & 21 & $11.14 \pm 4.40$ & 76.00 & 0.00 & 19 & $16.42 \pm 2.52$ & 41.00 & 1.00 & 0.485 \\
\hline
\end{tabular}

OCHRA toxin was detected in 21 samples $(100 \%)$ of the Iraqi manufactures and 19 samples $(100 \%)$ from the Iranian manufactures (Table 1), in concentration ranging from $3.00-4.00 \mu \mathrm{g} / \mathrm{kg}$, and $2.00-4.00 \mu \mathrm{g} / \mathrm{kg}$ respectively. Prevalence of OCHRA contamination revealed a non-significant $(\mathrm{P}>0.05)$ between the Iraqi and Iranian manufacture. Ochratoxin, are considered to be mycotoxins that develop during storage. The regulatory limits for Ochratoxin have not been ascertained in United States. European Commission (19) suggested a maximum level of $5 \mathrm{ppb}$ for Ochratoxin A in raw wheat, barley, and rye in international trade as food contaminants. No suggestions have been made for acceptable levels in animal or poultry feed. In another study in Argentina, Ochratoxin A was found in $38 \%$ of the poultry feed samples tested range from 25 to 30 (20). Beg et al. (18) found in their study in Kuwait, that the highest average concentration of Ochratoxin was found in layer mash feed $9.6 \mathrm{ppb}$ and the lowest in wheat bran $4.6 \mathrm{ppb}$. However, the maximum value of $>40 \mathrm{ppb}$ was detected in a soybean meal sample.

$\mathrm{T} 2$ toxin was detected in 21 samples $(100 \%)$ of the Iraqi manufacture and 19 samples (100\%) from the Iranian manufactures (Table 1), in concentration ranging from 2.00 $-16.00 \mu \mathrm{g} / \mathrm{kg}$, and $2.00-23.00 \mu \mathrm{g} / \mathrm{kg}$ respectively. Prevalence of T2 contamination revealed a significant association $(\mathrm{P}<0.05)$ between the Iraqi and Iranian manufactures. T-2 toxin are some of the mycotoxins that can significantly impact the health and productivity of poultry species (21). In poultry, the T-2 toxin has been the causative agent for mouth and intestinal lesions in addition to the impairment of immune responses, destruction of the hematopoietic system, declining egg production, the thinning of egg shells, refusal of feed, weight loss and altered feather patterns, abnormal positioning of the wings, hysteroid seizures or an impaired righting reflex (22).

FUM3 toxin was detected in 21 samples $(100 \%)$ of the Iraqi manufactures and 19 samples $(100 \%)$ from the Iranian 
manufactures (Table 1), in concentration ranging from 0.05 $-5.00 \mu \mathrm{g} / \mathrm{kg}$, and $0.10-2.50 \mu \mathrm{g} / \mathrm{kg}$ respectively. Prevalence of FUM3 contamination revealed a significant association $(\mathrm{P}<0.05)$ between the Iraqi and Iranian manufactures. Fumonisin is a mycotoxin produced by Fusarium spp associated with field contamination and development. This organism is considered present in virtually every seed, and sometimes there is a considerable amount of fumonisin present in symptomless kernels (18). In Taiwan, occurrence of fumonisin in imported maize was examined, and the level in only a few samples exceeded the $0.3 \mathrm{ppm}$ value (23). In a study from Iran (24), fumonisin B1 in maize from two areas was present at mean levels of 3.18 ppm (range from 0.68 to 7 ) and $0.22 \mathrm{ppm}$ (range from 0.01 to 0.88 ). In the study of Beg et al. (18), $>86 \%$ of samples tested positive for fumonisin. The average concentration was lowest in soybean meal is $1.42 \mathrm{ppm}$ and highest in broiler finisher feed is $3.2 \mathrm{ppm}$. These values, however, were, lower than the $30 \mathrm{ppm}$ maximum acceptable concentration for breeding poultry and egg-laying hens.

ZEAR3 toxin was detected in 15 samples $(71.42 \%)$ of the Iraqi manufactures and 19 samples $(100 \%)$ from the Iranian manufactures (Table 1), in concentration ranging from $2.00-76.00 \mu \mathrm{g} / \mathrm{kg}$, and $1.00-41.00 \mu \mathrm{g} / \mathrm{kg}$ respectively. Prevalence of ZEAR3 contamination revealed a significant association $(\mathrm{P}<0.05)$ between the Iraqi and Iranian manufactures, the highest prevalence was observed in Iranian samples is $100 \%$, whereas it least in Iraqi samples is $71.42 \%$. Zearalenone is another important mycotoxin produced by Fusarium spp and is detected along with other mycotoxins in a variety of grains, food, and feed material. It exerts estrogenic effects, and swine appeared to be the most sensitive animal. No regulations have been imposed with regard to the occurrence of this toxin. Weak piglet and litter size have been attributed to the levels of 0.5 to $1.0 \mathrm{ppm}$ dietary zearalenone.

Gajecki (25) recommended a tolerable daily intake of $0.2 \mathrm{mg} / \mathrm{kg}$ body weights for animals. Regarding poultry, limited information is available on the adverse effects of zearalenone (26). Zearalenone is receiving serious attention (27) for control, but its regulation poses complexities and needs further insight (28).

\section{References}

1. Assensi F, Abarca M, Cabanes F. Occurence of aspergillus species in mixed feeds and component raw materials and their ability to produce ochratoxin A. Food Microbiol. 2004;21:623-627. doi:10.1016/j.fm.2003.12.003

2. Charoenpornsook K, Kavisarasai P. Mycotoxins in animal feedstuffs of thailand. KMITL Sci Tech J. 2006;6:25-28.

3. Khan S, Shamsul H, Rozina S, Muhammad A. Occurrence of aflatoxin B1 in poultry feed and feed ingredients in Pakistan. International Journal of Agro Veterinary and Medical Sciences. 2011;5:30-42.
4. Anjum M, Sahota A, Akram M, Ali I. Prevalence of mycotoxins in poultry feed and feed ingredients in Panjab (Pakistan). J Anim Pl Sci. 2011;22:268-272.

5. Sokolovic M, Garaj-Vrhovac V, Simpraga B. T-2 toxin: Incidence and toxicity in poultry. Arh Hig Rada Toksikol. 2008;59:43-52. Doi:10.2478/10004-1254-59-2008-1843

6. Reddy A, Reddy V, Rao P, Yadagiri B. Effect of experimentally induced aflatoxicosis on the performance of commercial broiler chicks. Indian J Anim Sci. 1982;52(6):405-410.

7. Fujioka T, Kondou R, Fukuhara A. Efficacy of glycyrrhizin suppository for treatment of chronic hepatitis C: A pilot study. Hepatol Res. 2003;26(1):103-117. Doi:10.1016/s13866346(02)00332-7

8. Dhanasekaran D, Annamalai P, Noorudin T. Evaluation of aflatoxicosis in hens fed with commercial poultry feed. Turkish J Vet Anim Sci. 2009;33:385-391. Doi:10.3906/vet-0801-21

9. Hussain Z, Muhammad Z, Ahrar K, Ijaz J, Muhammad K, Sultan M. Residues of Aflatoxin B1 in broiler meat: effect of age and dietary aflatoxin B1 levels. Food Chem Toxicol. 2010;48:3304-3307. Doi:10.1016/j.fct.2010.08.016

10. Oguz H, Kecec T, Birdane Y, Onder F, Kurtoglu V. Effect of clinoptilolite on serum biochemical and haematological characters of broiler chickens during experimental aflatoxicosis. Res Vet Sci. 2000;69:89-93. Doi:10.1053/rvsc.2000.0395

11. Qureshi M, Brake J, Hamilton P, Hagler W, Nasheim S. Dietary exposure of broiler breeders to aflatoxin results in immune dysfunction in progeny chicks. Poult Sci. 1998;77:812-819. Doi:10.1093/ps/77.6.812

12. Dafalla R, Yagi A, Adam S. Experimental aflatoxicosis in hybro-type chicks; sequential changes in growth and serum constiluents and histopathological changes. Vet Hum Txicol. 1987;29:222-225.

13. Fink GJ. Mycotoxins: Their implications for human and animal health. Vet Qual. 1999;21:115-120. Doi:10.1080/01652176.1999.9695005

14. Rustom IYS. Aflatoxin in food and feed: Occurrence, legislation and inactivation by physical methods. Food Chem. 1997;59:57-67. Doi:10.1616/S0308-8146(96)00096-9

15. Nizamlyoglu F, Oguz H. Occurrence of aflatoxins in layer feed and corn samples in Konya province, Turkey. Food Addit Contam. 2003;20:654-658. Doi:10.1080/02652030303842

16. Dawlatana M, Coker RD, Nagler MJ, Wild CP, Hassan MS, Blunden G.The occurrence of mycotoxins in key commodities in Bangladesh: Surveillance results from 1993 to 1995. J Natural Toxins. 2002;11:379-386.

17. Thirumala-Devi K, Mayo MA, Reddy G, Reddy DV. Occurrence of aflatoxins and ochratoxin A in Indian poultry feeds. J Food Prot. 2002;65:1338-1340. Doi:10.4315/0362-028X-65.8.1338

18. Beg MU, Al-Mutairi M, Beg KR, Al-Mazeedi HM, Ali LN, Saeed T. Mycotoxins in poultry feed in Kuwait. Arch Environ Contam Toxicol. 2005;50:594-602. Doi:10.1007/S002244-005-2094-0

19. ECC. Comments on the draft maximum level for ochratoxin A in wheat, barley and rye and derived products submitted in response to CL2001/34-FAC (CX/FAC 02/18). European Commission, Brussels, Belgium; 2002.

20. Dalcero A, Magnoli C, Hallak C, Chiacchiera SM, Palacio G, Rosa CA. Detection of ochratoxin A in animal feeds and capacity to produce this mycotoxin by Aspergillus section Nigri in Argentina. Food Add Contam. 2002;19:1065-1072. Doi:10.1080/026520302101518995

21. Murugesan GR, Ledoux DR, Naehre, K, Berthiller F, Applegate TJ, Grenier B, Phillips T D, Schatzmayr G. Prevalence and effects of mycotoxins on poultry health and performance, and recent development in mycotoxin counteracting strategies. Poult Sci. 2015;94:1298-1315. Doi:10.3382/ps/pev075

22. Akande KE, Abubakar MM, Adegbola TA, Bogoro SE. Nutritional and health implications of mycotoxins in animal feeds: A review. Pak J Nutr. 2006;5:398-403. Doi:10.3923/pjn.2006.398.403 
23. Tseng TC, Liu CY. Occurrence of fumonisin B1 in maize imported into Taiwan. Int J Food Microbiol. 2001;65:23-26. Doi:10.1016/S0168-1605(00)00507-9

24. Shephard GS, Marasas WF, Yazdanpanah H, Rahimian H, Safavi N, Zarghi A. Fumonisin B (1) in maize harvested in Iran during 1999. Food Add Contam. 2002;19:676-679. Doi:10.1080/02652030210126541

25. Gajecki M. Zearalenone - undesirable substances in feed. Pol J Vet Sci. 2002;5:117-122.

26. Danicke S, Ueberschar KH, Halle I, Matthes S, Valenta H, Flachowsky G. Effect of addition of a detoxifying agent to laying hen diets containing uncontaminated or Fusarium toxin contaminated maize on performance of hens and carryover of zearalenone. Poult Sci. 2002;81:1671-1680. Doi:10.1093/ps/81.11.1671

27. Mitterbauer R, Weindorfer H, Safaie N, Krska R, Lemmens M, Ruckenbauer P. A sensitive and inexpensive yeast bioassay for the mycotoxin zearalenone and other compounds with estrogenic activity. Appl Environ Microbiol. 2003;69:805-811. Doi:10.1128/AEM.69.2.805-811.2003

28. Park DL, Troxell TC. US perspective on mycotoxin regulatory issues. Adv Exp Med Biol. 2002;504:277-285. Doi:10.1007/978-1-46150629-4. 